\title{
Enhancement of C-phycocyanin productivity by Arthrospira platensis when growing on palm oil mill effluent in a two-stage semi-continuous cultivation mode
}

\author{
M. M. Azimatun Nur ${ }^{1,2}$ (D) G. M. Garcia ${ }^{2}$ P. Boelen ${ }^{2} \cdot$ A. G. J. Buma ${ }^{2}$ \\ Received: 7 January 2019 /Revised and accepted: 8 April 2019 /Published online: 8 May 2019 \\ (C) The Author(s) 2019
}

\begin{abstract}
Palm oil mill effluent (POME) is well known as agricultural wastewater that has a high potential as a medium for microalgal growth due to its high macro- and micronutrient content. The cyanobacterium Arthrospira platensis is considered as a species with a high C-phycocyanin (C-PC) content which is important for fine chemical and pharmaceutical applications. However, cultivation of $A$. platensis on POME to produce economically feasible amounts of C-PC has not been well explored. For this, environmental, nutritional, and cultivation modes (batch, semi-continuous) were varied to optimize C-PC productivity when cultivated at various POME concentrations. Arthrospira platensis was found to grow well on POME. Highest biomass and C-PC concentrations were found on 30-100\% POME. Central composite rotatable design (CCRD) response surface methodology demonstrated that C-PC productivity was influenced by urea addition at the optimum salinity. The highest C-PC productivity was found on $100 \%$ POME during semi-continuous cultivation, while the addition of phosphorus and urea did not significantly improve C-PC productivity. By applying semi-continuous cultivation with 50\% POME at the first stage and $100 \%$ POME at the second stage, a similarly high C-PC productivity (4.08 $\pm 1.3 \mathrm{mg} \mathrm{L}^{-1}$ day ${ }^{-1}$ ) was achieved as compared with (artificial) Zarrouk medium during batch cultivation. We conclude that, when using a two-stage semi-continuous cultivation process, $A$. platensis can produce economically feasible amounts of C-PC when cultivated on 100\% POME.
\end{abstract}

Keywords Wastewater $\cdot$ Light intensity $\cdot$ Urea $\cdot$ C-PC $\cdot$ Arthrospira platensis, semi-continuous

\section{Introduction}

Cyanobacteria, including Arthrospira platensis, have an enormous commercial interest due to their high protein content (up to $70 \%$ ), essential amino acids, fatty acids (palmitic, linoleic, and oleic acids), and pigments (Abed et al. 2009; de la Jara et al. 2018). Their main pigments are chlorophyll- $a$, phycobiliproteins, and $\beta$-carotene (Soni et al. 2017).

Electronic supplementary material The online version of this article (https://doi.org/10.1007/s10811-019-01806-9) contains supplementary material, which is available to authorized users.

M. M. Azimatun Nur

m.m.azimatun.nur@rug.nl; lanaazim@upnyk.ac.id

1 Department of Chemical Engineering, Faculty of Industrial Technology, Universitas Pembangunan Nasional "Veteran", Yogyakarta, Indonesia

2 Department of Ocean Ecosystems, Energy and Sustainability Research Institute, Faculty of Science and Engineering, University of Groningen, Groningen, The Netherlands
Phycobiliprotein, mainly consisting of C-phycocyanin (C$\mathrm{PC}$ ), is a pigment well known for its antioxidant, anti-inflammatory, and anticarcinogenic functions (Wu et al. 2016; de la Jara et al. 2018). C-PC is one of the major light harvesting cyanobacterial pigments but it functions also as a storage protein in A. platensis (Boussiba and Richmond 1980; Hemlata and Fatma 2009). Furthermore, the bulk biomass of A. platensis contains high potential sources of various end products such as bioethanol derived from carbohydrates, food, and feed supplements due to its high protein and fatty acids content, apart from cosmetic products such as skin health lotion (Nur and Hadiyanto 2013; Raja et al. 2016). However, large amounts of water are required for cultivation and the high costs of synthetic fertilizers for mass cultivation of the algae are still the main issue (Zhai et al. 2017). Regarding this problem, wastewater which contains high nutrient levels has been proposed as the solution to achieve economically feasible cultivation conditions (Nur et al., 2019a).

One of the promising wastewaters to be used as a growth medium for algae is palm oil mill effluent (POME) which is generated from oil palm factories. POME contains high 
amounts of phosphorus, nitrogen, and micronutrients (Mohd Udaiyappan et al. 2017; Nur and Buma 2018). As reported earlier, POME addition promotes the growth of the fucoxanthin and sulfated exopolysaccharide producing marine diatom Phaeodactylum tricornutum (Nur et al. 2019a, b). Other researchers found that about $1 \%$ of raw POME supplemented to a commercial medium could promote the growth of A. platensis resulting in $12 \% \mathrm{dw}$ of C-PC by applying fedbatch cultivation (Sukumaran et al. 2014). Nevertheless, this small fraction of raw POME would not be sustainable when used in a large-scale industry since the high cost of the commercial fertilizer used in the cultivation as well as high demand of clean freshwater would compete with human consumption. Another study showed that $90 \%$ of POME could be used as a growth medium for A. platensis using continuous cultivation (Suharyanto et al. 2014). Conversely, continuous cultivation is not easily applicable in large-scale systems since the operation and the maintenance need special equipment and skilled labor, and the cost of the construction is still high (Lehr and Posten 2009; Fernandes et al. 2015). Finally, several studies demonstrated the utilization of POME by using dilution and or synthetic fertilizer supplementation (Sari et al. 2012; Nur et al. 2016). However, these reports were not focused on the optimization of C-PC productivity.

Nutritional and environmental factors such as salinity, irradiance, nitrogen availability, and cultivation mode (batch, semi-continuous, or continuous) regulate pigment productivity (Bezerra et al. 2011; Liu et al. 2016; Ho et al. 2018). The biomass (expressed as dry weight) productivity of $A$. platensis could be enhanced by employing semi-continuous batch cultivation to prevent nutrient limitation and self-shading (Radmann et al. 2007; Moreira et al. 2016). With respect to wastewater utilization, Chaiklahan et al. (2010) reported that cultivation of A. platensis on pig wastewater supplemented with bicarbonate and urea by employing a semi-continuous cultivation mode could press the cost of commercial medium up to 4.4 times compared to modified Zarrouk medium. However, based on our knowledge, this cultivation mode has not been tested for A. platensis grown on POME medium.

Recently, Benvenuti et al. (2016) showed that the biomass productivity of Nannochloropsis sp. could be increased by enriching commercial medium with nitrogen in a semicontinuous cultivation mode. For the present study, it was therefore hypothesized that semi-continuous cultivation could enhance the biomass and C-PC productivity of A. platensis cultured on POME medium after optimizing nutrient and other environmental conditions. Semi-continuous cultivation employs two-stage cultivations. In the first stage, microalgae are cultivated in batch mode until they reach ideal growth conditions during the exponential phase. In the second stage, a fraction of the culture is replaced by a new medium at the constant time and volume intervals (Radmann et al. 2007). The objective of this study was to optimize the productivity of C-PC from A. platensis cultivated on POME medium by employing semi-continuous cultivation at its optimal nutritional and environmental conditions.

\section{Material and methods}

\section{Wastewater preparation}

POME was obtained from a small factory in Sumatra, Indonesia, after it had been released from an aerobic open pond lagoon. The wastewater was stored in the freezer ($20{ }^{\circ} \mathrm{C}$ ) until use, to avoid nutrient degradation over time. Prior to experimental use, POME was thawed and filtered (GF/C glass fiber filter, Whatman) for removal of suspended solids and autoclaved at $121{ }^{\circ} \mathrm{C}$ for 15 mins. The wastewater contained $1245 \mathrm{mg} \mathrm{L}^{-1} \mathrm{COD}, 72.4 \mathrm{mg} \mathrm{L}^{-1}$ total $\mathrm{N}$, and $7.93 \mathrm{mg} \mathrm{L}^{-1} \mathrm{PO}_{4}{ }^{3-} \mathrm{P}$, as estimated previously using appropriate assay kits LCK349 and LCK138 (Hach Lange) (Nur et al. 2019b).

\section{Experimental setup}

Arthrospira platensis (SAG 21.99) was obtained from the Algal Culture Collection of the University of Göttingen (Sammlung von Algenkulturen der Universität Göttingen, SAG). Growth and maintenance of the culture were done in Zarrouk medium (Zarrouk 1966), which has a salinity of 12 PSU, in an illuminated U-shaped water basin at $27{ }^{\circ} \mathrm{C}$ in a 16:8 h light:dark cycle, at an irradiance of $150 \mu \mathrm{mol}$ photons $\mathrm{m}^{-2} \mathrm{~s}^{-1}$. The cultures were acclimated to the experimental conditions for at least 1 week prior to experimentation. In total, five experiments were done using a stepwise approach (Table 1). First, we investigated the effect of irradiance and nitrogen concentration on A. platensis biomass and C-PC productivity, grown in standard growth medium (experiment 1). Secondly, A. platensis was grown on different dilutions of POME to determine the optimal POME concentration for biomass productivity and C-PC concentration (experiment 2). Environmental and nutritional conditions were further investigated to determine the interactive effects of light intensity, nitrogen, salinity, and POME concentration on C-PC concentration by using full factorial design (experiment 3 ). As the nitrogen source, we first chose nitrate; however, given the much lower cost as a nitrogen source and the proven capability to support the growth of A. platensis, urea was added in the subsequent experiments (Cost et al. 2001). The optimum urea concentration as promising nitrogen source was investigated given the possible toxic effects at higher urea concentrations. Furthermore, salinity was optimized since POME contains a relatively low salinity (experiment 4). Finally, A. platensis was cultured in a semi-continuous mode at varying nutrient conditions by adding urea or phosphorus, in order to unravel the 
Table 1 Type of experimental setups, factors, and responses. n/a means not applicable

\begin{tabular}{|c|c|c|c|c|}
\hline Type of experiment & Factors & $\begin{array}{l}\text { Mode of } \\
\text { cultivation }\end{array}$ & Design of experiment & Responses \\
\hline Experiment 1 & Light intensity, nitrate & Batch & $\mathrm{n} / \mathrm{a}$ & $\mathrm{P}_{\text {biomass }}, \mathrm{C}-\mathrm{PC}, \mathrm{P}_{\mathrm{C}-\mathrm{PC}}$ \\
\hline Experiment 2 & POME & Batch & $\mathrm{n} / \mathrm{a}$ & $\mathrm{P}_{\text {biomass }}, \mathrm{C}-\mathrm{PC}$ \\
\hline Experiment 3 & Light intensity, nitrate, salinity, POME & Batch & Full factorial design & C-PC \\
\hline Experiment 4 & Urea, salinity & Batch & CCRD & Growth rate, $\mathrm{P}_{\text {biomass }}, \mathrm{C}-\mathrm{PC}, \mathrm{P}_{\mathrm{C}-\mathrm{PC}}$ \\
\hline Experiment 5 & POME, urea, phosphate & Batch, semi-continuous & $\mathrm{n} / \mathrm{a}$ & $\mathrm{P}_{\text {biomass }}, \mathrm{P}_{\mathrm{C}-\mathrm{PC}}$ \\
\hline
\end{tabular}

impact of N:P ratio on biomass and C-PC productivity during semi-continuous cultivation (experiment 5). Experimental conditions for each experiment are further described below.

\section{Experiment 1: effect of nitrogen concentration and light intensity on biomass and C-PC productivity (no POME addition)}

Cultures of A. platensis were grown in triplicate on Zarrouk medium in plastic $40-\mathrm{mL}$ cell culture flasks (Greiner Bio-One, ref. 690160). The flasks were placed in a photosynthetron equipped with a $250-\mathrm{W}$ lamp (MHN-TD power tone, Philips) (Kulk et al. 2011). The cultivation was done at two conditions: (i) Zarrouk medium as a standard medium containing replete nitrate at a concentration of $2.5 \mathrm{~g} \mathrm{~L}^{-1}(\mathrm{HN})$ and (ii) modified Zarrouk medium using $0.1 \mathrm{~g} \mathrm{~L}^{-1}$ nitrate as a source of nitrogen (LN). The photosynthetron allowed for exposure to 10 different light intensities $(I=8-800 \mu \mathrm{mol}$ photons $\left.\mathrm{m}^{-2} \mathrm{~s}^{-1}\right)$ and was controlled by a water bath $(27 \pm$ $\left.0.1^{\circ} \mathrm{C}\right)$. At the end of the exponential phase, samples $(4 \mathrm{~mL})$ were taken for immediate biomass measurements using spectrophotometry at $750 \mathrm{~nm}$. Dry biomass was calculated from the optical density as described below. The cultures were harvested for pigment analysis at the end of the exponential growth phase (4-7 days).

\section{Experiment 2: effect of POME on biomass productivity and C-PC concentration}

The algae were cultured in $75 \mathrm{~mL}$ working volume in $100 \mathrm{~mL}$ sterilized Erlenmeyer flasks placed in a U-shaped water bath (Lauda C 6 CS, B03008, Edition 2000 Constant Temp Immersion Heating circulating Water Bath) at $27{ }^{\circ} \mathrm{C}$ illuminated by a steady light source (Osram Biolux L 36 W/965) in a 16:8 h light:dark cycle (Van de Poll et al. 2007). Five percent $(v / v)$ of inoculum was used for the initial cultivation. Different dilutions of POME in ultrapure water provided by a Milli-Q purification system, further referred to as ultrapure water (Milli-Q), were used $(5-100 \% v / v)$. Final salinity was set to 4 PSU by using $\mathrm{NaCl}$ since natural 100\% POME has 4 PSU salinity. Initial $\mathrm{pH}$ was set to $9.0 \pm 0.2$ by using $2 \mathrm{~N} \mathrm{HCl}$ or $2 \mathrm{~N}$ $\mathrm{NaOH}$. Light intensity was set to $200 \mu \mathrm{mol}$ photons $\mathrm{m}^{-2} \mathrm{~s}^{-1}$ as measured in the center of the culture flask by using a spherical light sensor (Biospherical Instrument QSL2101, USA) which is small enough to be placed inside the culture flasks. At the end of the exponential phase (6 days), the optical density of the cells was measured by spectrophotometry at $750 \mathrm{~nm}$. Samples $(1.5 \mathrm{~mL})$ were taken and centrifuged at $10000 \mathrm{rpm}$ for $15 \mathrm{~min}$ to separate the algal biomass from the POME medium because of the possible interference of the color of POME in the spectrophotometry measurements. The pellet was washed twice using $0.75 \% \mathrm{NaCl}$ and resuspended in $1.5 \mathrm{~mL}$ ultrapure water (Milli-Q) at the experimental salinity of 4 PSU. Dry biomass was calculated based on the optical density as described below. The cultures were harvested for pigment analysis at the end of the exponential growth phase (6 days).

\section{Experiment 3: effects of nutritional and environmental conditions on the concentration of C-phycocyanin}

Arthrospira platensis was cultured in $75 \mathrm{~mL}$ working volume in $100-\mathrm{mL}$ sterilized Erlenmeyer flasks in a water bath as described above. Five percent $(v / v)$ of $A$. platensis culture was used as inoculate to autoclaved and filtered medium. A full factorial design with four variables (irradiance, salinity, nitrate, POME) was performed to reveal the influencing factors and the possible interaction between these factors with respect to C-PC productivity (Table 2). The experiments were carried out at $27^{\circ} \mathrm{C}$; the initial $\mathrm{pH}$ was adjusted to $9.0 \pm 0.2$ by using $2 \mathrm{~N} \mathrm{HCl}$ or $2 \mathrm{~N} \mathrm{NaOH}$. At the end of the exponential growth phase (7-10 days), the cultures were harvested for pigment analysis.

\section{Experiment 4: optimization of C-phycocyanin productivity}

Urea is considered a potential source of nitrogen for optimized cultivation of A. platensis on POME medium. However, high concentrations of urea are considered toxic for A. platensis due to the excess production of ammonium derived from microbial urea conversion. Furthermore, the optimal salinity for C-PC productivity is important to investigate for large-scale applications since it determines the water source (freshwater, seawater) that can be used for the dilution of POME. 
Table 2 Experimental factors of full factorial design and their levels to determine significant factors and their interactions on $\mathrm{P}$ biomass $\left(\mathrm{mg} \mathrm{L}^{-1}\right.$ day $\left.^{-1}\right)$ and C$\mathrm{PC}$ concentration $\left(\mathrm{mg} \mathrm{L}^{-1}\right)$. Mean values are based on two replicates $(n=2)$. Standard deviation is shown after \pm symbol

\begin{tabular}{|c|c|c|c|c|c|c|}
\hline \multirow[t]{2}{*}{ Run } & \multicolumn{4}{|l|}{ Variables } & \multicolumn{2}{|c|}{ C-PC $\left(\mathrm{mg} \mathrm{L}^{-1}\right)$} \\
\hline & POME (\%) & Salinity (PSU) & $\begin{array}{l}\text { Light intensity ( } \mu \mathrm{mol} \\
\text { photons } \mathrm{m}^{-2} \mathrm{~s}^{-1} \text { ) }\end{array}$ & Nitrate $\left(\mathrm{mg} \mathrm{L}^{-1}\right)$ & & \\
\hline 1 & 50 & 15 & 50 & 0 & 10.13 & \pm 4.80 \\
\hline 2 & 50 & 15 & 50 & 73 & 13.10 & \pm 5.26 \\
\hline 3 & 50 & 30 & 50 & 0 & 9.13 & \pm 0.55 \\
\hline 4 & 50 & 30 & 50 & 73 & 24.35 & \pm 16.73 \\
\hline 5 & 100 & 15 & 50 & 0 & 15.75 & \pm 2.90 \\
\hline 6 & 100 & 15 & 50 & 73 & 14.41 & \pm 1.35 \\
\hline 7 & 100 & 30 & 50 & 0 & 14.62 & \pm 3.17 \\
\hline 8 & 100 & 30 & 50 & 73 & 11.06 & \pm 0.53 \\
\hline 9 & 50 & 15 & 200 & 0 & 7.04 & \pm 0.36 \\
\hline 10 & 50 & 15 & 200 & 73 & 11.71 & \pm 2.21 \\
\hline 11 & 50 & 30 & 200 & 0 & 5.07 & \pm 0.31 \\
\hline 12 & 50 & 30 & 200 & 73 & 12.87 & \pm 8.67 \\
\hline 13 & 100 & 15 & 200 & 0 & 10.69 & \pm 2.05 \\
\hline 14 & 100 & 15 & 200 & 73 & 8.05 & \pm 0.57 \\
\hline 15 & 100 & 30 & 200 & 0 & 6.74 & \pm 0.62 \\
\hline 16 & 100 & 30 & 200 & 73 & 12.16 & \pm 2.50 \\
\hline
\end{tabular}

Therefore, it is important to obtain optimal values of salinity and urea addition, which were all expected to show optimal values with respect to growth, biomass, and C-PC productivity. The optimum growth conditions, significance and the interactive effects of salinity and urea addition on C-PC production, and biomass productivity by $A$. platensis were studied using central composite rotatable design (CCRD) response surface methodology (RSM). To this end, a total of 13 experimental runs were executed (Table 3 ). The ranges used for these experiments were $36,150,425,700$, and $813 \mathrm{mg} \mathrm{L}^{-1}$ for urea concentration $\left(x_{1}\right)$, and 5, 10, 22.5, 35, and 40 PSU for salinity $\left(x_{2}\right)$. The empirical form of the second order polynomial model (Eq. 1) can be described as follows:

$y=\beta_{0}+\sum \beta_{\mathrm{i}} x_{\mathrm{i}}+\sum \beta_{\mathrm{ii}} x_{\mathrm{i}}^{2}+\sum \beta_{\mathrm{ij}} x_{\mathrm{i},} x_{\mathrm{j}}$

where $y$ is the predicted value; $\beta_{0}, \beta_{\mathrm{i}}, \beta_{\mathrm{ii}}$, and $\beta_{\mathrm{ij}}$ are a constant, linear, quadratic, and the interaction coefficient, respectively; and $x_{\mathrm{i}}$ and $x_{\mathrm{j}}$ are independent variables of the model.

Cultivation was carried out in the same setup as experiment 3. Fifty percent of POME was used and mixed with ultrapure

Table 3 Design of the experiments generated from RSM and the responses. Mean values are based on two replicates $(n=2)$. Standard deviation is shown after \pm symbol

\begin{tabular}{lclllllll}
\hline Run & Point type & Block & $\begin{array}{l}\text { Urea addition } \\
\left(\mathrm{mg} \mathrm{L}^{-1}\right)\end{array}$ & Salinity (PSU) & Growth rate $\left(\right.$ day $\left.^{-1}\right)$ & $P_{\text {biomass }}\left(\mathrm{mg} \mathrm{L}^{-1}\right.$ day $\left.^{-1}\right)$ & $\mathrm{C}-\mathrm{PC}_{\left(\mathrm{mg} \mathrm{L}^{-1}\right)} P_{\mathrm{C}-\mathrm{PC}}\left(\mathrm{mg} \mathrm{L}^{-1}\right.$ day \\
\hline 1 & 0 & 1 & 425 & 22.5 & $0.24 \pm 0.04$ & $24.79 \pm 0.77$ & $19.56 \pm 0.18$ & $2.79 \pm 0.04$ \\
2 & -1 & 1 & 814 & 22.5 & $0.27 \pm 0.04$ & $32.41 \pm 0.24$ & $22.23 \pm 0.09$ & $3.18 \pm 0.02$ \\
3 & 1 & 1 & 150 & 10 & $0.15 \pm 0.05$ & $12.46 \pm 1.19$ & $14.11 \pm 0.37$ & $2.02 \pm 0.08$ \\
4 & -1 & 1 & 425 & 40 & $0.18 \pm 0.04$ & $12.63 \pm 0.00$ & $12.31 \pm 0.66$ & $1.76 \pm 0.13$ \\
5 & 1 & 1 & 150 & 35 & $0.19 \pm 0.03$ & $10.90 \pm 3.75$ & $11.42 \pm 0.38$ & $1.63 \pm 0.08$ \\
6 & 1 & 1 & 700 & 10 & $0.18 \pm 0.07$ & $26.60 \pm 0.60$ & $17.20 \pm 0.81$ & $2.46 \pm 0.16$ \\
7 & 0 & 1 & 425 & 22.5 & $0.29 \pm 0.04$ & $36.66 \pm 2.92$ & $21.81 \pm 0.74$ & $3.12 \pm 0.15$ \\
8 & 0 & 1 & 425 & 22.5 & $0.23 \pm 0.04$ & $33.84 \pm 2.14$ & $22.67 \pm 0.58$ & $3.24 \pm 0.12$ \\
9 & 0 & 1 & 425 & 22.5 & $0.27 \pm 0.05$ & $22.94 \pm 0.77$ & $17.18 \pm 0.24$ & $2.45 \pm 0.05$ \\
10 & -1 & 1 & 36 & 22.5 & $0.26 \pm 0.07$ & $25.32 \pm 3.72$ & $17.11 \pm 0.50$ & $2.44 \pm 0.10$ \\
11 & 1 & 1 & 700 & 35 & $0.26 \pm 0.02$ & $19.49 \pm 1.96$ & $16.57 \pm 0.30$ & $2.37 \pm 0.06$ \\
12 & 0 & 1 & 425 & 22.5 & $0.30 \pm 0.07$ & $32.20 \pm 7.44$ & $20.20 \pm 1.47$ & $2.89 \pm 0.30$ \\
13 & -1 & 1 & 425 & 5 & $0.06 \pm 0.02$ & $4.67 \pm 0.54$ & $7.28 \pm 0.10$ & $1.04 \pm 0.02$ \\
\hline
\end{tabular}


water (Milli-Q), $\mathrm{NaCl}$, or natural filter sterilized seawater to adjust the salinity. Light intensity was set inside the culture media at $175 \mu \mathrm{mol}$ photons $\mathrm{m}^{-2} \mathrm{~s}^{-1}$, and the initial $\mathrm{pH}$ was adjusted to $9.0 \pm 0.2$ by using $2 \mathrm{~N} \mathrm{HCl}$ or $2 \mathrm{~N} \mathrm{NaOH}$. Every day, $1.5 \mathrm{~mL}$ of the culture was measured by spectrophotometry to determine the growth rate. At the end of the exponential phase (7 days), the cultures were harvested to measure dry biomass and C-PC content.

\section{Experiment 5: semi-continuous cultivation}

For the semi-continuous cultivation, two serial cultivation modes were applied. At the first stage, A. platensis was cultivated in batch in 50\% POME with or without urea, until the end of the exponential phase was reached (4 days). In the second stage, $30 \%$ of the cultures were replaced with fresh medium daily, using different medium compositions (Table 5). Cultivation was carried out in the same setup as experiment 3 . The initial salinity at the first cultivation stage was adjusted to 22.5 PSU by using natural seawater, following the outcome of experiment 4 . In experiment 5 , phosphate $\left(3 \mathrm{mg} \mathrm{L}^{-1}\right.$, run 4$)$ or urea (800 $\mathrm{mg} \mathrm{L}^{-1}$, run 5) was added at the second stage. Initial light intensity was set inside the culture media at $175 \mu \mathrm{mol}$ photons $\mathrm{m}^{-2} \mathrm{~s}^{-1}$, and the initial $\mathrm{pH}$ was adjusted to $9.0 \pm 0.2$ by using $2 \mathrm{~N} \mathrm{HCl}$ or $2 \mathrm{~N} \mathrm{NaOH}$. Every day, $1 \mathrm{~mL}$ of the sample was taken to determine the growth profile. The cultures were harvested at the pseudo-steady-state conditions to measure $\mathrm{C}$ $\mathrm{PC}$ and dry biomass. The pseudo-steady-state conditions were reached when the cell concentration was almost constant in two consecutive measurements of semi-continuous cultivation (Bezerra et al. 2011).

\section{Analysis}

\section{Growth rate}

The growth rate was calculated from the linear regression of the natural logarithm of optical density at $750 \mathrm{~nm}$, which correspond to the dry biomass versus time (Eq. 2).

$\mu=\frac{\ln \mathrm{X}_{2}-\ln \mathrm{X}_{1}}{\mathrm{t}_{2}-\mathrm{t}_{1}}$

where $\mu$ is growth rate $\left(\right.$ day $\left.^{-1}\right), X_{2}$ is the optical density at time $t_{2}(\mathrm{~d})$, and $X_{1}$ the optical density at time $t_{1}(\mathrm{~d})$. Conversion of $\mathrm{OD}_{750}$ to dry biomass for $A$. platensis was done as described previously (Griffiths et al. 2011; Lari et al. 2018) using a A. platensis suspension obtained from the end of exponential growth. The suspension was diluted by five serial dilutions which resulted in different cell concentrations. Determination of cell dry weight of $A$. platensis was done using the gravimetric method. The culture sample $(30 \mathrm{~mL})$ was harvested by filtering over pre-dried and pre-weighed $\mathrm{GF} / \mathrm{C}$ filters. The filters were washed with $0.5 \mathrm{M} \mathrm{NH}_{3} \mathrm{HCO}_{3}$ according to $\mathrm{Zhu}$ and Lee (1997). Then, the filter was dried at $75^{\circ} \mathrm{C}$ until a constant weight was reached. Equation 3 was used as a regression between the biomass dry weight and the optical density at $750 \mathrm{~nm}$.

$y=0.59\left(\mathrm{OD}_{750}\right)-0.03 \quad R 2=0.98$

where $y$ is biomass dry weight $\left(\mathrm{g} \mathrm{L}^{-1}\right)$ and $\mathrm{OD}_{750}$ is optical density at $750 \mathrm{~nm}$ (Supplementary 3).

\section{C-PC analysis}

Ten milliliter of the sample was centrifuged at $4500 \mathrm{rpm}$ for 30 mins. The pellet obtained was stored at $-20{ }^{\circ} \mathrm{C}$ until analysis. Extraction was conducted by adding $3 \mathrm{~mL}$ of cold buffer phosphate $(\mathrm{pH}=6.8)$ followed by two times freezing and thawing, and sonication at 50\% amplitude for 2 min using an ultrasound probe (Vibra Cell, VC 130 PB, USA) following Sarada et al. (1999) and Tavanandi et al. (2018). The filtrate was separated from the pellet by centrifugation $(4500 \mathrm{rpm}$, $\left.4{ }^{\circ} \mathrm{C}, 30 \mathrm{mins}\right)$. The concentration of C-PC was determined using a spectrophotometer (Hach DR 3400), by measuring the optical density at $620 \mathrm{~nm}$ and $652 \mathrm{~nm}$ (Moraes et al. 2011). The concentration of C-PC was determined as

$\mathrm{C}-\mathrm{PC}=\frac{\mathrm{OD}_{620}-0.474\left(\mathrm{OD}_{652}\right)}{5.34}$

and volumetric C-PC productivity (Eq. 5) was determined by the biomass productivity and the specific pigment content in the biomass (Eriksen 2008; Nur et al. 2019a).

$P_{\mathrm{C}-\mathrm{PC}}=\frac{\left(N_{\mathrm{h}}-N_{0}\right) \cdot C_{\mathrm{p}}}{t}$

where C-PC is the concentration of C-PC $\left(\mathrm{mg} \mathrm{mL}^{-1}\right), P_{\mathrm{C}-\mathrm{PC}}$ is C-PC productivity ( $\mathrm{mg} \mathrm{L}^{-1}$ day $\left.^{-1}\right), N_{\mathrm{h}}$ is final biomass $\left(\mathrm{mg} \mathrm{L}^{-1}\right), N_{0}$ is initial biomass $\left(\mathrm{mg} \mathrm{L}^{-1}\right), C_{\mathrm{p}}$ is pigment content $(\% \mathrm{w} / \mathrm{w})$, and $t$ is the total duration of the cultivation (d).

For the volumetric C-PC productivity in semi-continuous cultivation, Eq. 6 was employed based on Bezerra et al. (2011).

$P_{\mathrm{C}-\mathrm{PC}}=D \cdot X_{\mathrm{s}} \cdot C_{\mathrm{p}}$

where $P_{\mathrm{C}-\mathrm{PC}}$ is C-PC productivity $\left(\mathrm{mg} \mathrm{L}^{-1}\right.$ day $^{-1}$ ), $D$ is dilution rate $\left(\mathrm{d}^{-1}\right), X_{\mathrm{s}}$ is biomass concentration at pseudo-steadystate condition $\left(\mathrm{mg} \mathrm{L}^{-1}\right)$, and $C_{\mathrm{p}}$ is pigment content $(\% \mathrm{w} / \mathrm{w})$.

\section{Statistical analysis}

Minitab ver. 18 (demo version) was employed for statistical analysis and evaluation for full factorial and CCRD design. Differences between treatments were analyzed with two-way 
analysis of variance (ANOVA) at a $P$ value of 0.05 or 0.01 . Post hoc tests (Tukey HSD) were performed for pair-wise comparisons. The experimental results were recorded based on at least two replicates and expressed as the means and standard deviations ( $\pm \mathrm{SD})$.

\section{Results}

\section{Effect of irradiance and nitrogen concentration on biomass and C-PC productivity}

Biomass productivity of A. platensis growing on Zarrouk medium without POME (experiment 1 ) varied significantly with initial nitrogen (nitrate) concentration and irradiance (Fig. 1). Three types of light responses were distinguished: low light (LL, $\leq 100 \mu \mathrm{mol}$ photons $\mathrm{m}^{-2} \mathrm{~s}^{-1}$ ), medium light (ML, 100$300 \mu \mathrm{mol}$ photons $\mathrm{m}^{-2} \mathrm{~s}^{-1}$ ), and high light (HL, $\geq 300 \mu \mathrm{mol}$ photons $\mathrm{m}^{-2} \mathrm{~s}^{-1}$ ). While the initial nitrate in the medium was varied as $\mathrm{HN}\left(1.8 \mathrm{~g} \mathrm{~L}^{-1}\right.$ nitrate) and $\mathrm{LN}\left(73 \mathrm{mg} \mathrm{L}^{-1}\right.$ nitrate). At LL, biomass productivity was not influenced by nitrate availability $(\mathrm{HN} / \mathrm{LN})(P>0.05)$. At $\mathrm{HL}$, however, the biomass productivity was affected by nitrate availability $(P<0.01)$. The highest biomass productivity was found at standard (HN) Zarrouk medium at $300 \mu \mathrm{mol}$ photons $\mathrm{m}^{-2} \mathrm{~s}^{-1}$ (Fig. 1a). C-PC content (percentage of C-PC, when normalized to calculated dry weight) was found to be both irradiance and nitrate dependent (Fig. 1b). The C-PC content was found to be significantly lower at $\mathrm{HL}$ compared to ML $(P<0.01)$. Both C-PC content and productivity were significantly higher at ML and HN (around $130 \mu \mathrm{mol}$ photons $\left.\mathrm{m}^{-2} \mathrm{~s}^{-1}\right)$ compared to $\mathrm{LN}(P<0.05)$. With respect to C-PC concentration (final $\mathrm{mg} \mathrm{C}-\mathrm{PC}$ per liter of culture, Fig. 1c), the highest value was found at around 150$200 \mu \mathrm{mol}$ photons $\mathrm{m}^{-2} \mathrm{~s}^{-1}$ for both nitrate conditions. Finally, C-PC content and productivity (Fig. 1d) were significantly different when comparing the two nutrient conditions $(P<0.05)$.

\section{Effect of different POME fractions}

In experiment 2, between 5 and 30\% POME on A. platensis biomass productivity was significantly enhanced $(P<0.05)$ (Fig. 2). At 5\% POME, the lowest biomass productivity $\left(3.95 \pm 3.1 \mathrm{mg} \mathrm{L}^{-1} \mathrm{day}^{-1}\right)$ was recorded, while at $100 \%$ POME, the biomass productivity reached up to $23.08 \pm$ $3.6 \mathrm{mg} \mathrm{L}^{-1}$ day $^{-1}$. Increasing POME concentrations also significantly enhanced the concentration of C-PC from $4.75 \pm$ $0.5 \mathrm{mg} \mathrm{L}^{-1}$ at $5 \%$ compared to $12.96 \pm 2.8 \mathrm{mg} \mathrm{L}^{-1}$ at $100 \%$ POME $(P<0.05)$. However, increasing POME from 30 to $100 \%$ did not significantly enhance biomass productivity and C-PC concentration $(P>0.05)$ (Fig. 2).

\section{Effect of environmental and nutritional conditions on C-PC concentration}

Full factorial design in experiment 3 was employed to reveal the most influencing factors for C-PC concentration of A. platensis cultivated under different environmental and nutritional conditions (Table 2). The most influencing factor for C-PC concentration was irradiance, followed by the interaction of POME concentration and nitrate addition (Fig. 3). At low POME and low nitrate addition, C-PC concentration was recorded to be around $8 \mathrm{mg} \mathrm{L}^{-1}$. When $100 \mathrm{mg} \mathrm{L}^{-1}$ of nitrate was added to 50\% POME, C-PC concentration increased up to $14.8 \mathrm{mg} \mathrm{L}^{-1}$. Addition of $100 \mathrm{mg} \mathrm{L}^{-1}$ nitrate to $100 \%$ POME resulted in a slightly lower C-PC concentration of $12.4 \mathrm{mg} \mathrm{L}^{-1}$ (Fig. 4). Based on this finding, nitrogen addition was further investigated in the next experiment, by utilizing urea as a nitrogen source. Furthermore, salinity did not seem to significantly affect the C-PC concentration, perhaps due to the low range used (15-35 PSU). In the next experiment, the range was therefore expanded to find the optimal salinity.

\section{Effect of urea addition and salinity on C-PC productivity}

In experiment 4, 50\% $v / v$ POME was used as culture medium for A. platensis while varying salinity and urea addition. Based on CCRD RSM optimization urea both in the linear and quadratic form, salinity in the linear form and the interaction of urea and salinity did not significantly influence growth rate and biomass productivity. Optimal salinity for growth and biomass productivity was recorded at 20-23 PSU (Fig. 5a and b). As for C-PC concentration, salinity in the linear form and the interaction of urea and salinity did not significantly enhance the production (Table 4, Fig. 5c). However, salinity in the quadratic form and urea addition in the linear form were found to be significantly related to C-PC productivity (Fig. 5d). This indicated that the highest salinity level did not always result in the highest C-PC productivity, while the addition of urea above $813 \mathrm{mg} \mathrm{L}^{-1}$ could still improve C-PC productivity. The optimal C-PC concentration was recorded as $22.7 \mathrm{mg} \mathrm{L}^{-1}$ at $813 \mathrm{mg} \mathrm{L}^{-1}$ urea and $22.7 \mathrm{PSU}$ salinity (Fig. 5c).

\section{Effect of nutrient condition and cultivation mode on biomass and C-PC productivity}

In experiment 5, the effects of POME, urea, and phosphate addition on biomass and $\mathrm{C}-\mathrm{PC}$ productivity were investigated during the semi-continuous cultivation of $A$. platensis. Biomass and C-PC productivity were significantly enhanced in run 5 (growth medium containing 50\% POME at the first stage and $100 \%$ POME supplemented with $800 \mathrm{mg} \mathrm{L}^{-1}$ of urea at the second stage), resulting in $70.0 \pm$ 
Fig. 1 Effect of irradiance and nitrate availability on a biomass productivity, b C-phycocyanin content, $\mathbf{c}$ C-PC concentration, $\mathbf{d}$ C-PC productivity. Closed circle $(\bullet)$ is standard Zarrouk medium using $1.8 \mathrm{~g} \mathrm{~L}^{-1}$ nitrate $(\mathrm{HN})$, open circle (o) is modified Zarrouk medium using $73 \mathrm{mg} \mathrm{L}^{-1}$ nitrate (LN). Average values of triplicate cultures are shown. Error bars indicate the SD of the mean $(n=3)$. Values that do not share letters are significantly different $(P<0.05)$ a

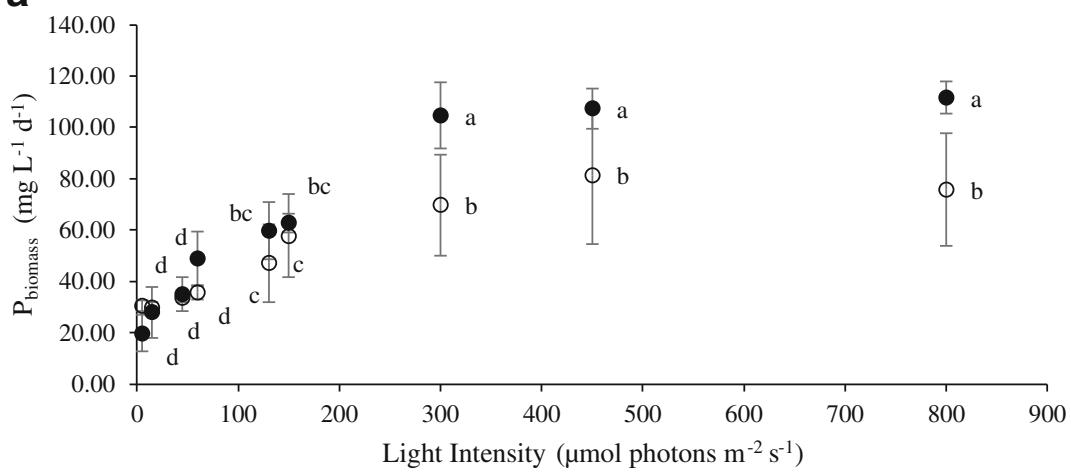

b

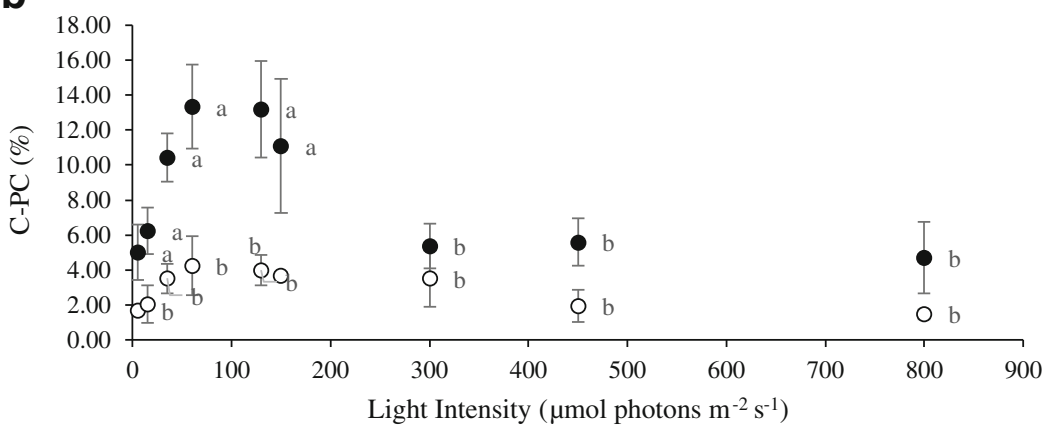

C

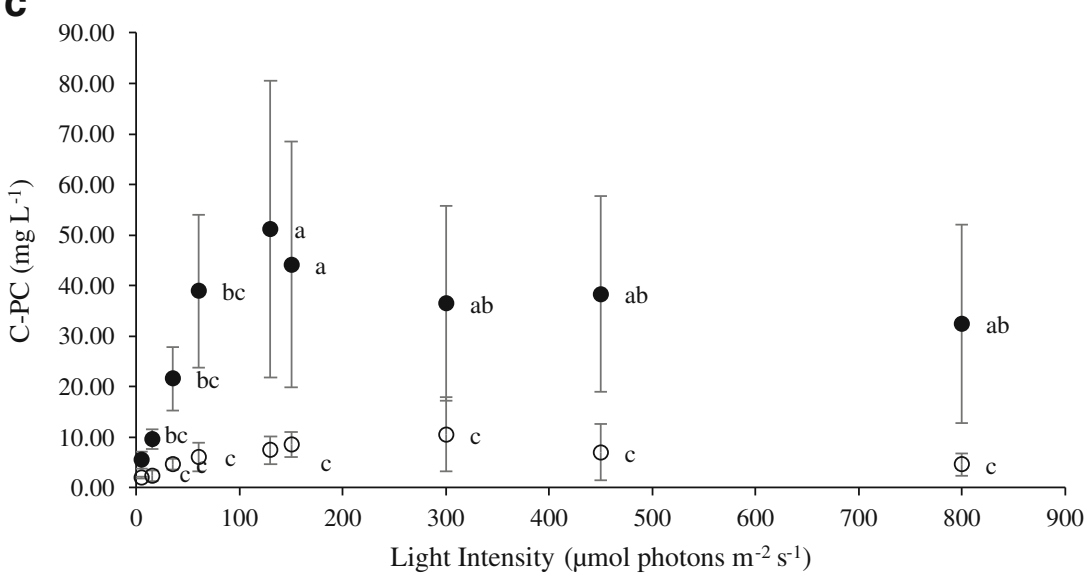

d

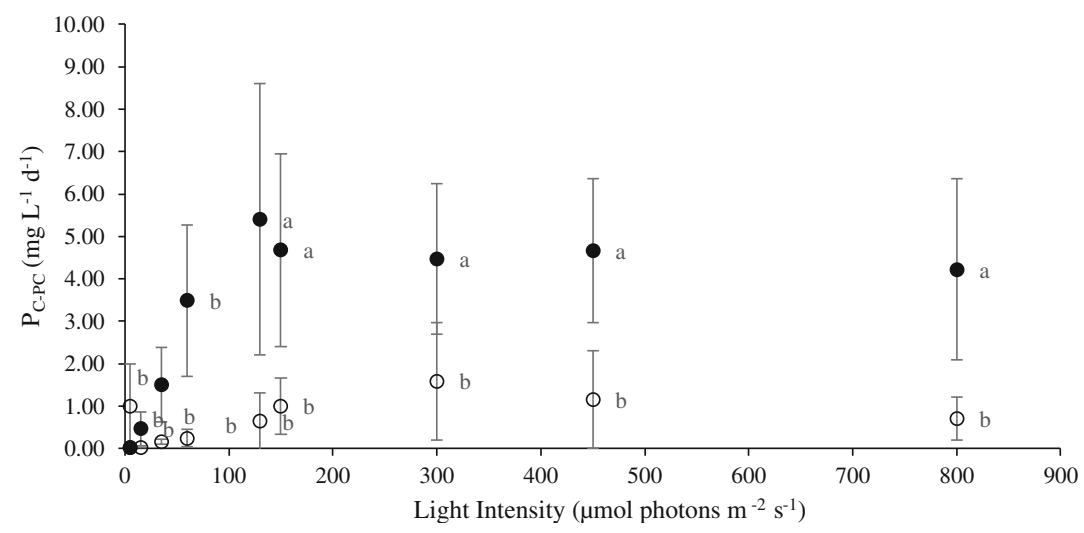

$1.6 \mathrm{mg} \mathrm{L}^{-1}$ day $^{-1}$ and $4.43 \pm 0.22 \mathrm{mg} \mathrm{L}^{-1}$ day $^{-1}$ of biomass and $\mathrm{C}-\mathrm{PC}$ productivity, respectively, compared to run 2
$(P<0.05)$. Run 2, (50\% POME at both the first and second stage, no addition of urea), showed the lowest biomass and $\mathrm{C}$ - 
Fig. 2 Biomass productivity (Pbiomass) and C-PC concentration of $A$. platensis cultivated on different POME fractions in ultrapure water (Milli-Q) at 4 PSU salinity and $200 \mu \mathrm{mol}$ photons $\mathrm{m}^{-2} \mathrm{~s}^{-1}$. Average values of duplicate cultures are shown. Error bars indicate the SD of the mean. Closed circle is biomass productivity. Open circle is $\mathrm{C}-\mathrm{PC}$ production

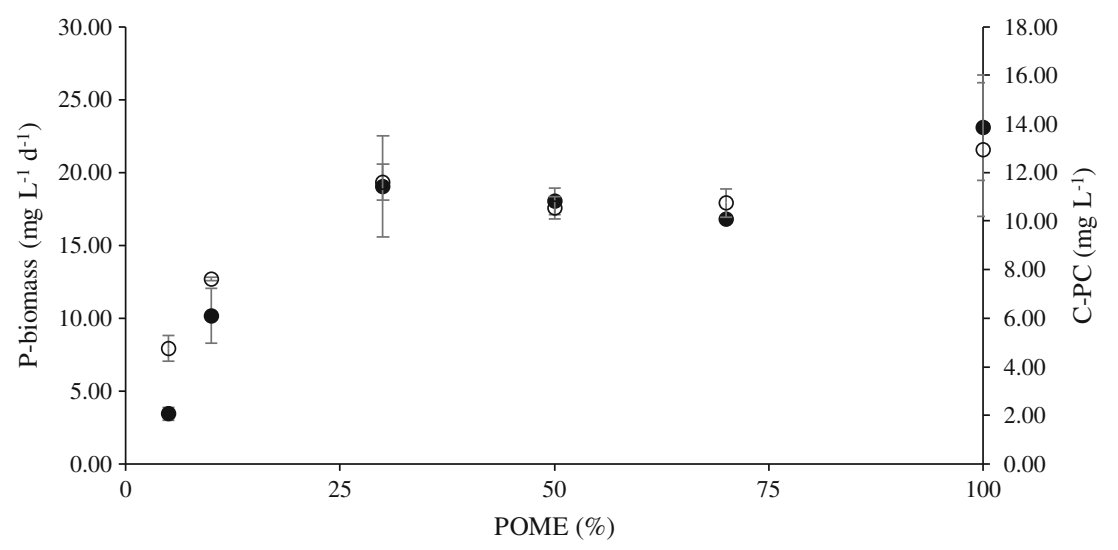

PC productivity compared to run 1 and $5(P<0.05)$ (Table 5$)$. In run 4 , the addition of phosphate during the second stage did not significantly influence biomass and C-PC productivity. The C-PC productivity in run 5 reached $62.76 \pm$ $3.67 \mathrm{mg} \mathrm{L}^{-1}$ day $^{-1}$ and $5.76 \pm 1.85 \mathrm{mg} \mathrm{L}^{-1}$ day $^{-1}$ for biomass and C-PC productivity, respectively, which was comparable to control Zarrouk medium carried out in batch cultivation mode (Fig. 1). Finally, these values were 2.2-fold higher compared to the batch cultivation mode that had 50\% POME and $800 \mathrm{mg} \mathrm{L}^{-1}$ urea (Fig. 5, Table 5).

\section{Discussion}

When developing large-scale production systems, it is vital to know how irradiance and nitrogen availability affect C-PC productivity (Ho et al. 2018). C-PC is a major light harvesting pigment that can also serve as a storage protein in blue-green algae, including A. platensis (Boussiba and Richmond 1980; Vonshak et al. 1982; Rastogi et al. 2015). This study showed that cellular C-PC content is strongly dependent on irradiance and nitrate availability (Fig. 1b). This implies that supra- optimal irradiance and lack of nitrogen availability levels in large-scale cultivation system would not benefit biomass and C-PC productivity.

However, biomass productivity was not dependent on nitrogen availability below saturating irradiance levels $(P>0.05)$ (Fig. 1a). A similar result was found in previous studies in which it was demonstrated that biomass production was unchanged in nitrogen-deficient medium compared to Zarrouk medium at low light, while protein production and C-PC content were decreased (Olguín et al. 2001; Sala et al. 2018). When A. platensis was cultivated at high light, growth increased and resulted in a higher nitrogen demand. Furthermore, when nitrogen availability was not high enough to support growth, A. platensis produced lower biomass levels, resulting in lower C-PC concentrations (Fig. 1a and b). In order to maintain metabolic functions, C-PC may be used as an intracellular nitrogen storage compound by A. platensis anticipating nitrogen-limiting conditions (Boussiba and Richmond 1980; Eriksen 2008). Therefore, to guarantee high C-PC productivity, cultivation conditions should carefully be maintained at optimal irradiance and nitrogen levels.
Fig. 3 Pareto chart showing the effects of (combinations of) parameters on the C-PC concentration of A. platensis. The vertical line indicates the significance of the effects at $95 \%$ confidence level. A is POME, B is salinity, C is irradiance, and $\mathrm{D}$ is nitrate

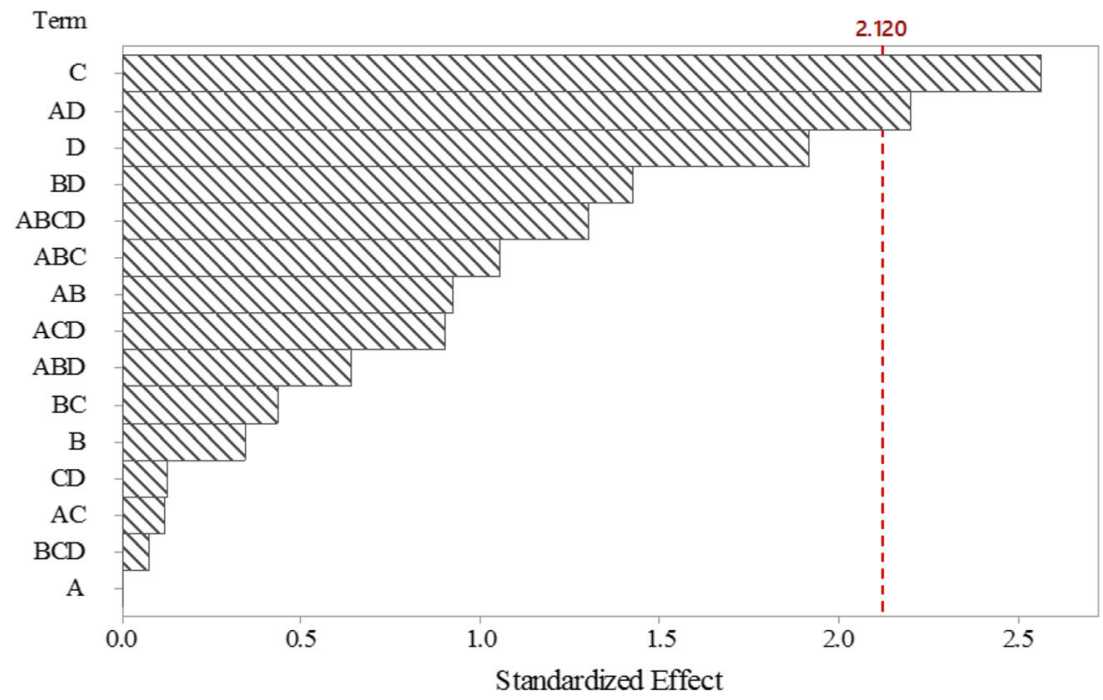




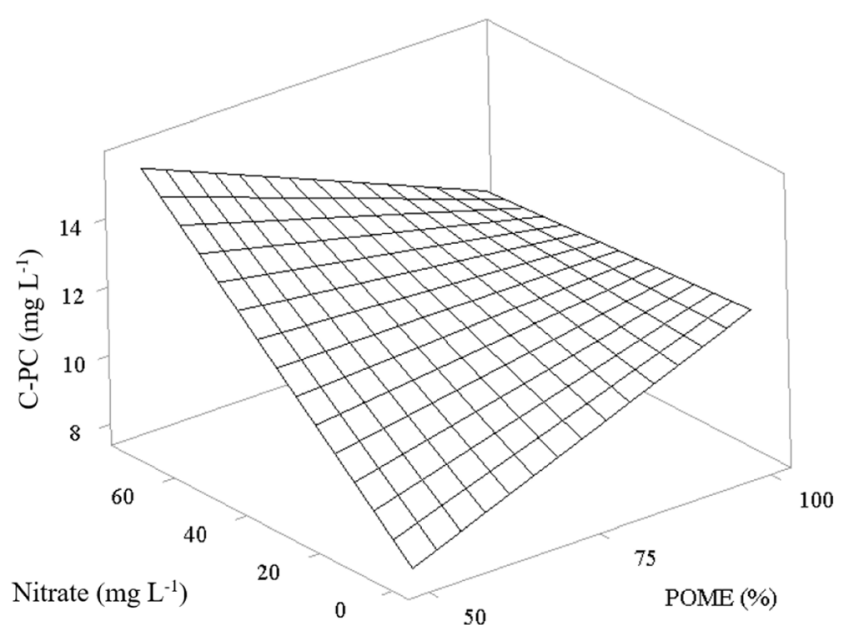

Fig. 4 Response surface plot (3D) of a C-PC concentration as a function of nitrate addition and POME concentration at salinity 22.5 PSU and irradiance $125 \mu \mathrm{mol}$ photons $\mathrm{m}^{-2} \mathrm{~s}^{-1}$

In our study, biomass productivity and C-PC concentration were also dependent on POME fraction (Fig. 2). Arthrospira platensis grew well on 30-100\% v/v POME at a

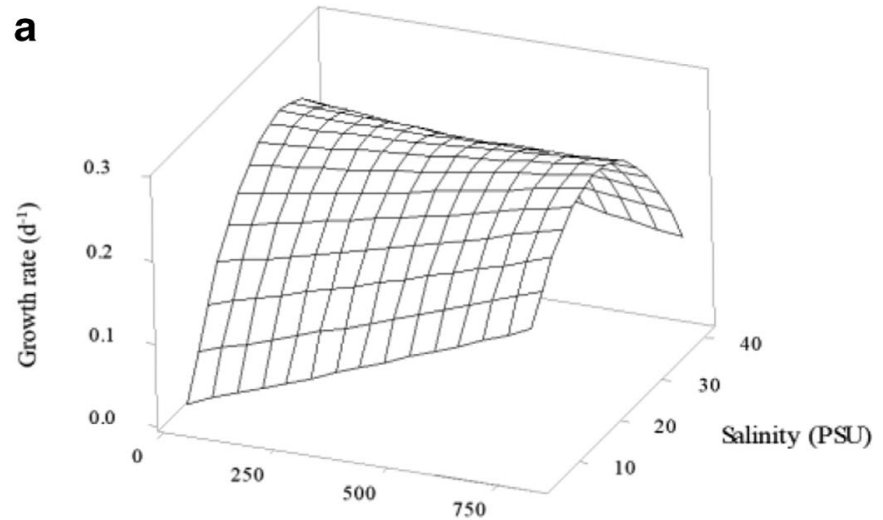

Urea $\left(\mathrm{mg} \mathrm{L}^{-1}\right)$

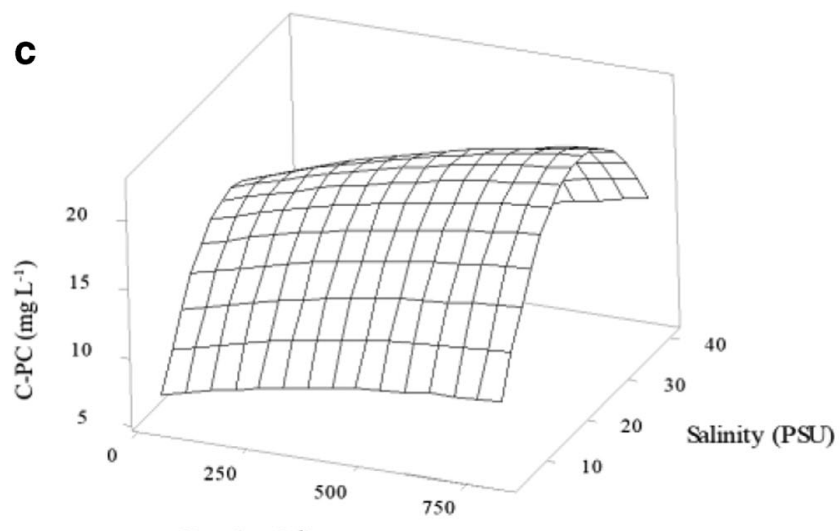

Urea $\left(\mathrm{mg} \mathrm{L}^{-1}\right)$

Fig. 5 Response surface plots (3D) showing the effects of salinity (PSU), and urea $\left(\mathrm{mg} \mathrm{L}^{-1}\right)$ on a growth rate $\left(\mathrm{day}^{-1}\right)$, b biomass productivity $(\mathrm{P}-$ biomass, $\mathrm{mg} \mathrm{L}^{-1} \mathrm{day}^{-1}$ ), c C-PC concentration (C-PC, $\mathrm{mg} \mathrm{L}^{-1}$ ), and $\mathbf{d ~ C}$ - saturating irradiance level. This implies that A. platensis can tolerate the high ammonia levels present in the POME, which may reach concentrations up to $100 \mathrm{mg} \mathrm{L}^{-1}$ (Sasongko et al. 2015). In support of this, Carvalho et al. (2004) reported that A. platensis can tolerate an ammonia concentration of $6.4 \mathrm{mM}$ $\left(109 \mathrm{mg} \mathrm{L}^{-1}\right)$ whereas growth was totally inhibited at $26 \mathrm{mM}$. In contrast, previous research had shown that the growth of other algal species was inhibited when using more than 30 and $50 \% v / v$ of digested POME (Cheirsilp et al. 2017; Cheah et al. 2018; Nur et al. 2019b). This underlines the tolerance of Arthrospira to the high ammonia levels or other potentially toxic substances (e.g., phenolic compounds) present in POME.

Based on experiment 2, the highest influencing factor was irradiance, in accordance with the results of experiment 1 (Fig. 1). The second most influencing factor was the interaction of nitrate addition and POME concentration (Fig. 3). As stressed before, C-PC functions primarily as the main light harvesting pigment, but it has a second role as a storage compound. The highest C-PC concentration was found at $50 \%$ POME with the addition of nitrate compared to other

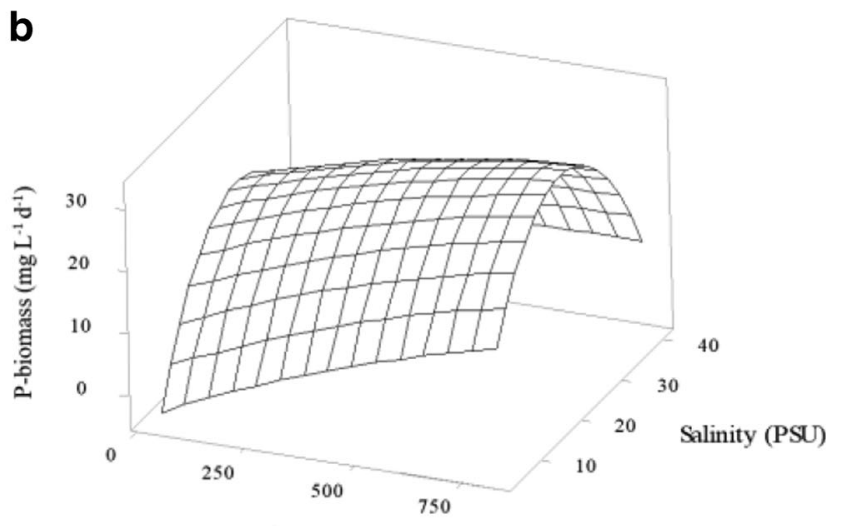

Urea ( $\left.\mathrm{mg} \mathrm{L}^{-1}\right)$

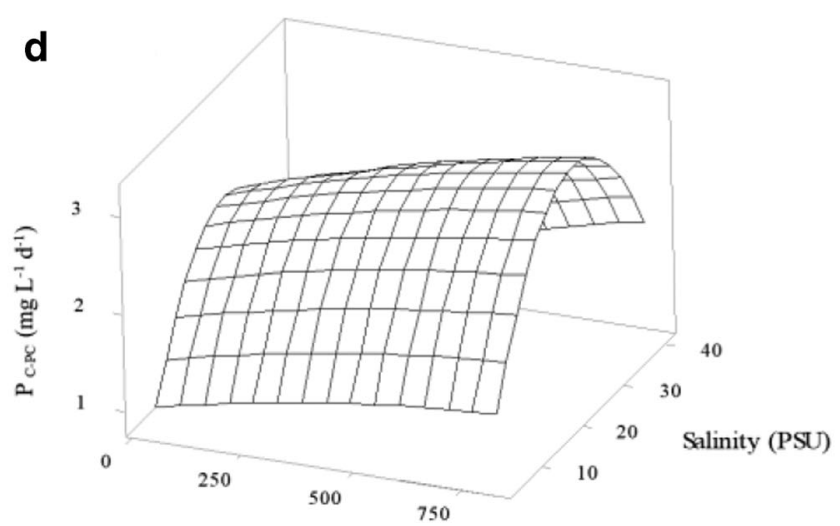

Urea ( $\left.\mathrm{mg} \mathrm{L} \mathrm{L}^{-1}\right)$

PC productivity $\left(\mathrm{P}_{\mathrm{C}-\mathrm{PC}}, \mathrm{mg} \mathrm{L}^{-1}\right.$ day $^{-1}$ ) generated by A. platensis cultivated on 50\% POME at $175 \mu \mathrm{mol}$ photons $\mathrm{m}^{-2} \mathrm{~s}^{-1}$ 
Table 4 ANOVA of C-PC concentration generated from CCRD. Values are significant at $P<0.01$

\begin{tabular}{|c|c|c|c|c|c|c|}
\hline Source & $\mathrm{DF}$ & Adj SS & Adj MS & $F$ value & $P$ Value & Remarks \\
\hline Model & 5 & 401.487 & 80.297 & 17.55 & $<0.01$ & Significant \\
\hline Linear & 2 & 69.988 & 34.994 & 7.65 & 0.003 & \\
\hline Urea $\left(\mathrm{mg} \mathrm{L}^{-1}\right)$ & 1 & 59.957 & 59.957 & 13.11 & $<0.01$ & Significant \\
\hline Salinity (PSU) & 1 & 10.031 & 10.031 & 2.19 & 0.154 & \\
\hline Square & 2 & 329.407 & 164.704 & 36.00 & 0.000 & \\
\hline Urea $\left(\mathrm{mg} \mathrm{L}^{-1}\right) \times$ urea $\left(\mathrm{mg} \mathrm{L}^{-1}\right)$ & 1 & 1.907 & 1.907 & 0.42 & 0.526 & \\
\hline Salinity $(\mathrm{PSU}) \times$ salinity $(\mathrm{PSU})$ & 1 & 328.443 & 328.443 & 71.80 & $<0.01$ & Significant \\
\hline 2-way interaction & 1 & 2.119 & 2.119 & 0.46 & 0.504 & \\
\hline Urea $\left(\mathrm{mg} \mathrm{L}^{-1}\right) \times$ salinity $(\mathrm{PSU})$ & 1 & 2.119 & 2.119 & 0.46 & 0.504 & \\
\hline Error & 20 & 91.489 & 4.574 & & & \\
\hline Lack-of-fit & 3 & 42.888 & 14.296 & 5.00 & 0.011 & Not significant \\
\hline Pure error & 17 & 48.602 & 2.859 & & & \\
\hline Total & 25 & 492.976 & & & & \\
\hline
\end{tabular}

treatments (Fig. 4). As reported before, the nitrogen to phosphorus ratio in the medium is important for pigment production (McClure et al. 2018). It seems that when nitrate was added to $100 \%$ POME, excess nitrogen was generated. Based on previous results, cultivation of $A$. platensis above the optimal nitrogen concentration in the medium could not enhance the C-PC concentration, since the excess nitrogen was not completely stored as C-PC pigment in A. platensis (Setyoningrum and Nur 2015). Based on this, 50\% of POME was used for subsequent experiments, while nitrate was replaced with urea as a relatively inexpensive alternative nitrogen source.

Salinity optimization may also be considered important with respect to large-scale cultivation. For example, to make large-scale cultivation sustainable, seawater might be preferred over drinking water or other freshwater sources, when diluting POME to the $50 \%$ level. Based on CCRD RSM, the optimal salinity with respect to growth rate, biomass, and $\mathrm{C}$ PC productivity was around 22-24 PSU, which is much higher than POME alone. In support of this, Liu et al. (2016) showed that the production of phycocyanin and carotene by $A$. platensis was optimal when using growth media supplemented with 200-400 mM NaCl, equaling 11.6-23.3 PSU, compared to control Zarrouk medium. The addition of urea significantly increased C-PC productivity and did not show inhibition up to $813 \mathrm{mg} \mathrm{L}^{-1}(P<0.05)$.

Semi-continuous cultivation generally stimulated biomass and C-PC productivity (Table 5). When $100 \%$ of POME was provided at the second stage of cultivation, the nutrient concentration was increased accordingly, while light intensity in the culture became lower due to the high turbidity of POME: from 175 to $90 \mu \mathrm{mol}$ photons $\mathrm{m}^{-2} \mathrm{~s}^{-1}$. The combination of nutrients and irradiance significantly affected biomass and $\mathrm{C}$ PC productivity in accordance with experiment 1 (Fig. 1). By adding extra urea at the second stage of cultivation, the biomass and C-PC productivity slightly increased but this difference was not significant, probably due to the enhanced availability of nitrogen for photosynthesis. This research is in agreement with Benvenuti et al. (2016) who found that the addition of $140 \mathrm{mg} \mathrm{L}^{-1}$ nitrogen enhanced biomass production of Nannochloropsis sp. when cultivated in semicontinuous mode compared to the $70 \mathrm{mg} \mathrm{L}^{-1}$ nitrogen concentration in the medium. Another study reported that semicontinuous cultivation could enhance biomass productivity

Table 5 Biomass and C-PC productivity of A. platensis cultivated on POME medium using consecutive two-stage cultivations. Mean values are based on 4 replicates. SD is shown after the \pm symbol. The same sharing letters represent no significant difference $(P>0.05)$

\begin{tabular}{|c|c|c|c|c|c|c|c|c|c|c|}
\hline \multirow[t]{2}{*}{ Run } & \multicolumn{3}{|c|}{ Stage 1 (batch) } & \multicolumn{3}{|c|}{ Stage 2 (semi-continuous) } & \multicolumn{2}{|c|}{$P_{\text {biomass }}\left(\mathrm{mg} \mathrm{L}^{-1}\right.$ day $\left.^{-1}\right)$} & \multicolumn{2}{|c|}{$P_{\mathrm{C}-\mathrm{PC}}\left(\mathrm{mg} \mathrm{L}^{-1}\right.$ day $\left.^{-1}\right)$} \\
\hline & Medium & $\begin{array}{l}\text { External } \\
\text { nutrient }\left(\mathrm{mg} \mathrm{L}^{-1}\right)\end{array}$ & Sources & Medium & $\begin{array}{l}\text { External } \\
\text { nutrient }\left(\mathrm{mg} \mathrm{L}^{-1}\right)\end{array}$ & Sources & & & & \\
\hline 1 & $50 \%$ POME & 800 & urea & $100 \%$ POME & - & - & 69.59 & $\pm 16.9^{\mathrm{a}}$ & 4.38 & $\pm 1.0^{\mathrm{a}}$ \\
\hline 2 & $50 \%$ POME & - & - & $50 \%$ POME & - & - & 44.05 & $\pm 5.5^{\mathrm{b}}$ & 2.58 & $\pm 0.5^{\mathrm{b}}$ \\
\hline 3 & $50 \%$ POME & - & - & $100 \%$ POME & - & - & 65.57 & $\pm 17.8^{\mathrm{ab}}$ & 4.08 & $\pm 1.3^{\mathrm{ab}}$ \\
\hline 4 & $50 \%$ POME & - & - & $100 \%$ POME & 3 & $\mathrm{PO}_{4}^{-}$ & 60.27 & $\pm 0.9^{\mathrm{ab}}$ & 3.74 & $\pm 0.3^{\mathrm{ab}}$ \\
\hline 5 & $50 \%$ POME & - & - & $100 \%$ POME & 800 & urea & 70.01 & $\pm 1.6^{\mathrm{a}}$ & 4.43 & $\pm 0.2^{\mathrm{a}}$ \\
\hline
\end{tabular}


Table 6 Biomass, C-PC productivity, and final C-PC concentration of A. platensis cultivated on POME under different conditions. n.a., not analyzed; n.ap, not applicable

\begin{tabular}{|c|c|c|c|c|c|c|c|}
\hline \multirow{2}{*}{$\begin{array}{l}\text { Type of } \\
\text { cultivation }\end{array}$} & \multicolumn{2}{|l|}{ Media } & \multirow{2}{*}{$\begin{array}{l}\text { Total } \\
\text { cultivation } \\
\text { time }\end{array}$} & \multirow{2}{*}{$\begin{array}{l}P_{\text {biomass }} \\
\left(\mathrm{mg} \mathrm{L}^{-1} \text { day }^{-1}\right)\end{array}$} & \multirow{2}{*}{$\begin{array}{l}P_{\mathrm{C}-\mathrm{PC}} \\
\left(\mathrm{mg} \mathrm{L}^{-1} \text { day }^{-1}\right)\end{array}$} & \multirow{2}{*}{$\begin{array}{l}\text { C-PC } \\
\left(\mathrm{mg} \mathrm{L}^{-1}\right)\end{array}$} & \multirow[t]{2}{*}{ References } \\
\hline & Media composition & External nutrient & & & & & \\
\hline Semi-continuous & $\begin{array}{l}50 \% v / v \text { POME }+50 \% v / v \text { natural } \\
\text { seawater (first stage) } \\
100 \% v / v \text { POME (second stage) }\end{array}$ & $800 \mathrm{mg} \mathrm{L}^{-1}$ urea & 8 day & 69.59 & 4.08 & 13.80 & This study \\
\hline Batch & $\begin{array}{l}50 \% v / v \text { POME }+50 \% \text { natural } \\
\text { seawater }\end{array}$ & $800 \mathrm{mg} \mathrm{L}^{-1}$ urea & 7 day & 33.64 & 2.05 & 22.69 & This study \\
\hline Batch & $100 \% v / v$ POME & n.ap & 6 day & 23.08 & 1.29 & 12.96 & This study \\
\hline Continuous & $\begin{array}{l}90 \% v / v \text { POME }+10 \% v / v \\
\text { commercial medium }\end{array}$ & $\begin{array}{l}\text { Commercial } \\
\text { medium }\end{array}$ & 14 day & 65.00 & n.a & n.a & $\begin{array}{l}\text { Suharyanto } \\
\text { et al. } 2014\end{array}$ \\
\hline Batch & $\begin{array}{l}30 \% v / v \text { POME }+70 \% v / v \\
\text { distilled water }\end{array}$ & n.ap & 13 day & 16.69 & n.a & n.a & $\begin{array}{l}\text { Nur } \\
\quad \text { et al. } 2016\end{array}$ \\
\hline Batch & $\begin{array}{l}20 \% v / v \text { POME }+80 \% v / v \\
\text { commercial medium }\end{array}$ & $\begin{array}{l}\text { Commercial } \\
\text { medium }\end{array}$ & 7 day & 28.50 & n.a & n.a & $\begin{array}{l}\text { Sari et al. } \\
2012\end{array}$ \\
\hline
\end{tabular}

and phycocyanin content of $A$. platensis cultivated on pig wastewater by supplementing the wastewater with sodium bicarbonate and urea. In their study, C-PC productivity under these conditions was similar to the control Zarrouk medium (Chaiklahan et al. 2010). Due to of the high phosphate levels present in the wastewater, the addition of urea could increase the nitrogen to phosphorus ratio, making phosphate potentially limiting and resulting in higher biomass and C-PC production.

In the present study, the addition of a phosphate at the second-stage cultivation did not significantly increase the biomass and C-PC productivity compared to the other treatments (experiment 5) $(P>0.05)$. This indicates that the enrichment of phosphorus, which resulted in a lower N:P ratio, did not significantly affect C-PC production. Another interesting result was shown in run 1 (growth medium containing $50 \%$ POME supplemented with $800 \mathrm{mg} \mathrm{L}^{-1}$ urea at the first stage and $100 \%$ POME at the second stage) where biomass and CPC productivity were significantly enhanced compared to run 2 (growth medium containing 50\% POME only at the first and second stage $)(P<0.05)$. This indicated that the addition of nitrogen at the first stage enhanced the initial biomass for semi-continuous cultivation (Supplementary 1). When $100 \%$ POME was added to the second stage, the nutrient could promote the growth of $A$. platensis which already had higher initial biomass compared to the other treatments.

To summarize, the best option for semi-continuous cultivation might be when based on run 3, which used 50\% POME at the first stage, and $100 \%$ of POME at the second stage without adding external nutrients (Table 5). This cultivation resulted in $65.6 \pm 17.9 \mathrm{mg} \mathrm{L}^{-1}$ day $^{-1}$ and $4.1 \pm 1.3 \mathrm{mg} \mathrm{L}^{-1}$ day $^{-1}$ for biomass and C-PC productivity, respectively. The result from run 3 was also higher compared to the batch cultivation systems used in previous research (Table 6). Our results are similar compared to a continuous cultivation system that used
$90 \%$ of POME and resulted in $65 \mathrm{mg} \mathrm{L}^{-1}$ day $^{-1}$ biomass productivity (Suharyanto et al. 2014). By employing the semi-continuous system, inhibitory factors such as selfshading and excess secondary products secreted by the cells could be avoided, thereby resulting in higher biomass productivity (Radmann et al. 2007; Moreira et al. 2016). By using seawater for cultivation, a dual benefit was achieved: the salinity could be increased at the first stage and the demand of freshwater or drinking water could be lowered, overall reducing the cost of cultivation. Furthermore, by utilizing a higher POME concentration at the second stage, large-scale cultivation would reach higher cost-effectiveness and feasibility due to inexpensive fertilizer derived from POME compared to the batch method which utilized low POME concentrations blended with commercial nutrients.

\section{Conclusion}

Irradiance and nitrogen concentration were the main factors driving C-PC productivity. Based on CCRD RSM, the optimal salinity was found to be 22.5 PSU, and no inhibition was found up to $813 \mathrm{mg} \mathrm{L}^{-1}$ of urea. Biomass and C-PC productivity of $A$. platensis cultivated on POME medium were successfully enhanced using a semi-continuous cultivation mode at $175 \mu \mathrm{mol}$ photons $\mathrm{m}^{-2} \mathrm{~s}^{-1}$ with $50 \%$ POME at the first stage and $100 \%$ POME at the second stage. This resulted in the highest C-PC productivity ( $4.08 \pm 1.3 \mathrm{mg} \mathrm{L}^{-1}$ day $\left.^{-1}\right)$, similar to the artificial control Zarrouk medium during batch cultivation.

Funding information This project is funded by Lembaga Pengelola Dana Pendidikan (LPDP), Kementerian Keuangan, Republik Indonesia (Reference no. PRJ-72/ LPDP.3/2016). 
Open Access This article is distributed under the terms of the Creative Commons Attribution 4.0 International License (http:// creativecommons.org/licenses/by/4.0/), which permits unrestricted use, distribution, and reproduction in any medium, provided you give appropriate credit to the original author(s) and the source, provide a link to the Creative Commons license, and indicate if changes were made.

\section{References}

Abed RMM, Dobretsov S, Sudesh K (2009) Applications of cyanobacteria in biotechnology. J Appl Microbiol 106:1-12

Benvenuti G, Lamers PP, Breuer G, Bosma R, Cerar A, Wijffels RH, Barbosa MJ (2016) Microalgal TAG production strategies: why batch beats repeated-batch. Biotechnol Biofuels 9:1-17

Bezerra RP, Montoya EYO, Sato S, Perego P, de Carvalho JCM, Converti A (2011) Effects of light intensity and dilution rate on the semicontinuous cultivation of Arthrospira (Spirulina) platensis. A kinetic Monod-type approach. Bioresour Technol 102:3215-3219

Boussiba S, Richmond AE (1980) C-phycocyanin as a storage protein in the blue-green alga Spirulina platensis. Arch Microbiol 125:143147

Carvalho JCM, Francisco FR, Almeida KA, Sato S, Converti A (2004) Cultivation of Arthrospira (Spirulina) platensis (Cyanophyceae) by fed-batch addition of ammonium chloride at exponentially increasing feeding rates. J Phycol 40:589-597

Chaiklahan R, Chirasuwan N, Siangdung W, Paithoonrangsarid K, Bunnag B (2010) Cultivation of Spirulina platensis using pig wastewater in a semi-continuous process. J Microbiol Biotechnol 20:609614

Cheah WY, Show PL, Juan JC, Chang JS, Ling TC (2018) Microalgae cultivation in palm oil mill effluent (POME) for lipid production and pollutants removal. Energy Convers Manag 174:430-438

Cheirsilp B, Tippayut J, Romprom P, Prasertsan P (2017) Phytoremediation of secondary effluent from palm oil mill by using oleaginous microalgae for integrated lipid production and pollutant removal. Waste Biomass Valoriz 8:2889-2897

Cost JAV, Cozz KL, Oliveira L, Magagnin G (2001) Different nitrogen sources and growth responses of Spirulina platensis in microenvironments. World J Microbiol Biotechnol 17:439-442

de la Jara A, Ruano-Rodriguez C, Polifrone M, Assunçao P, BritoCasillas Y, Wägner AM, Serra-Majem L (2018) Impact of dietary Arthrospira (Spirulina) biomass consumption on human health: main health targets and systematic review. J Appl Phycol 30: $2403-2423$

Eriksen NT (2008) Production of phycocyanin - a pigment with applications in biology, biotechnology, foods and medicine. Appl Microbiol Biotechnol 80:1-14

Fernandes BD, Mota A, Teixeira JA, Vicente AA (2015) Continuous cultivation of photosynthetic microorganisms: approaches, applications and future trends. Biotechnol Adv 33:1228-1245

Griffiths MJ, Garcin C, van Hille RP, Harrison STL (2011) Interference by pigment in the estimation of microalgal biomass concentration by optical density. J Microbiol Methods 85:119-123

Hemlata, Fatma T (2009) Screening of cyanobacteria for phycobiliproteins and effect of different environmental stress on its yield. Bull Environ Contam Toxicol 83:509-515

Ho SH, Liao JF, Chen CY, Chang JS (2018) Combining light strategies with recycled medium to enhance the economic feasibility of phycocyanin production with Spirulina platensis. Bioresour Technol 247:669-675

Kulk G, Van de Poll WH, Visser RJW, Buma AGJ (2011) Distinct differences in photoacclimation potential between prokaryotic and eukaryotic oceanic phytoplankton. J Exp Mar Biol Ecol 298:63-72
Lari Z, Abrishamchi P, Ahmadzadeh H, Soltani N (2018) Differential carbon partitioning and fatty acid composition in mixotrophic and autotrophic cultures of a new marine isolate Tetraselmis sp. KY114885. J Appl Phycol 31:201-210

Lehr F, Posten C (2009) Closed photobioreactors as tools for biofuel production. Curr Opin Biotechnol 20:280-285

Liu C, Li LJ, Wu CY, Guo KN, Li JH (2016) Growth and antioxidant production of Arthrospira in different $\mathrm{NaCl}$ concentrations. Biotechnol Lett 38:1089-1096

McClure DD, Luiz A, Gerber B, Barton GW, Kavanagh JM (2018) An investigation into the effect of culture conditions on fucoxanthin production using the marine microalgae Phaeodactylum tricornutum. Algal Res 29:41-48

Mohd Udaiyappan AF, Abu Hasan H, Takriff MS, Sheikh Abdullah SR (2017) A review of the potentials, challenges and current status of microalgae biomass applications in industrial wastewater treatment. J Water Process Eng 20:8-21

Moraes CC, Sala L, Cerveira GP, Kalil SJ (2011) C-Phycocyanin extraction from Spirulina platensis wet biomass. Braz J Chem Eng 28:45-49

Moreira JB, Costa JAV, de Morais MG (2016) Evaluation of different modes of operation for the production of Arthrospira sp. J Chem Technol Biotechnol 91:1345-1348

Nur MMA, Buma AGJ (2018) Opportunities and challenges of microalgal cultivation on wastewater, with special focus on palm oil mill effluent and the production of high value compounds. Waste Biomass Valor. https://doi.org/10.1007/s12649-018-0256-3

Nur MMA, Hadiyanto (2013) Utilization of agroindustry wastewater as growth medium for microalgae based bioenergy feedstock in Indonesia (an overview). J Sustain 1:3-7

Nur MMA, Kristanto D, Setyoningrum TM, Budiaman IGS (2016) Utilization of microalgae cultivated in palm oil mill wastewater to produce lipid and carbohydrate by employing microwave- assisted irradiation. Recent Innov Chem Eng 9:107-116

Nur MMA, Muizelaar W, Boelen P, Buma AGJ (2019a) Environmental and nutrient conditions influence fucoxanthin productivity of the marine diatom Phaeodactylum tricornutum grown on palm oil mill effluent. J Appl Phycol 31:111-122

Nur MMA, Swaminathan MK, Boelen P, Buma AGJ (2019b) Sulfated exopolysaccharide production and nutrient removal by the marine diatom Phaeodactylum tricornutum growing on palm oil mill effluent. J Appl Phycol https://doi.org/10.1007/s10811-019-01780-2

Olguín EJ, Galicia S, Angulo-Guerrero O, Hernández E (2001) The effect of low light flux and nitrogen deficiency on the chemical composition of Arthrospira sp. (Arthrospira) grown on digested pig waste. Bioresour Technol 77:19-24

Radmann EM, Reinehr CO, Costa JAV (2007) Optimization of the repeated batch cultivation of microalga Arthrospira platensis in open raceway ponds. Aquaculture 265:118-126

Raja R, Hemaiswarya S, Ganesan V, Carvalho IS (2016) Recent developments in therapeutic applications of Cyanobacteria. Crit Rev Microbiol 42:394-405

Rastogi RP, Sonani RR, Madamwar D (2015) Effects of PAR and UV radiation on the structural and functional integrity of phycocyanin, phycoerythrin and allophycocyanin isolated from the marine cyanobacterium Lyngbya sp. A09DM. Photochem Photobiol 91:837-844

Sala L, Ores J d C, Moraes CC, Kalil SJ (2018) Simultaneous production of phycobiliproteins and carbonic anhydrase by Spirulina platensis LEB-52. Can J Chem Eng 96:1896-1902

Sarada R, Pillai MG, Ravishankar GA (1999) Phycocyanin from Spirulina sp: Influence of processing of biomass on phycocyanin yield, analysis of efficacy of extraction methods and stability studies on phycocyanin. Process Biochem 34:795-801

Sari FYA, I Made AS, Hadiyanto H (2012) Kultivasi mikroalga Arthrospira platensis dalam media POME dengan variasi konsentrasi POME dan komposisi jumlah nutrien. J Teknol Kim Ind 1:487-494 
Sasongko NA, Noguchi R, Ahamed T, Takaigawa T (2015) Introduction of integrated energy plantation model for microalgae-using Palm Oil Mill Effluent (POME). J Jpn Inst Energy 94: 561-570

Setyoningrum TM, Nur MMA (2015) Optimization of C-phycocyanin production from $S$. platensis cultivated on mixotrophic condition by using response surface methodology. Biocatal Agric Biotechnol 4: 603-607

Soni RA, Sudhakar K, Rana RS (2017) Arthrospira - from growth to nutritional product: a review. Trends Food Sci Technol 69:157-171

Suharyanto, Panji T, Permatasari S, Syamsu K (2014) Production of Arthrospira platensis in continuous photobioreactor using palm oil mill effluent media. Menara Perkebunan 82:1-9

Sukumaran P, Nulit R, Zulkifly S, Halimoon N, Omar H, Ismail A (2014) Potential of fresh POME as a growth medium in mass production of Arthrospira platensis. Int J Curr Micorbiol Appl Sci 3:235-250

Tavanandi HA, Mittal R, Chandrasekhar J, Raghavarao KSMS (2018) Simple and efficient method for extraction of C-phycocyanin from dry biomass of Arthospira platensis. Algal Res 31:239-251

Van de Poll WH, Visser RJW, Buma AGJ (2007) Acclimation to a dynamic irradiance regime changes excessive irradiance sensitivity of Emiliania huxleyi and Thalassiosira weissflogii. Limnol Oceanogr 52:1430-1438
Vonshak A, Abeliovich A, Boussiba S, Arad S, Richmond A (1982) Production of Spirulina biomass: effects of environmental factors and population density. Biomass 2:175-185

Wu Q, Liu L, Miron A, Klímová B, Wan D, Kuča K (2016) The antioxidant, immunomodulatory, and anti-inflammatory activities of Spirulina: an overview. Arch Toxicol 90:1817-1840

Zarrouk C (1966) Contribution à l'étude d'une cyanophycée. Influence de divers facteurs physiques et chimiques sur la croissance et photosynthèse de Spirulina maxima Geitler. PhD Thesis, University of Paris

Zhai J, Li X, Li W, Rahaman MH, Zhao Y, Wei B, Wei H (2017) Optimization of biomass production and nutrients removal by Spirulina platensis from municipal wastewater. Ecol Eng 108: 83-92

Zhu CJ, Lee YK (1997) Determination of biomass dry weight of marine microalgae. J Appl Phycol 9:189-194

Publisher's note Springer Nature remains neutral with regard to jurisdictional claims in published maps and institutional affiliations. 